\title{
Sistem Informasi Geografis Pemetaan Lokasi ATM BNI Terdekat di Kota Serang Berbasis Android
}

\author{
Thoha Nurhadiyan ${ }^{1}$, A. Syamsul Hidayatullah ${ }^{2}$ \\ Program Studi Teknologi Informasi Fakultas Teknologi Informasi Universitas Serang Raya \\ Jln. Raya Cilegon Serang KM. 5 - Taman Drangong Kota Serang \\ ${ }^{1}$ thoha.nurhadiyan@gmail.com \\ ${ }^{2}$ Syamsul_hidayat@gmail.com
}

\begin{abstract}
Abstrak - ATM banyak ditemui di berbagai tempat umum dan strategis seperti pusat perbelanjaan, minimarket dan tempat khusus yang telah di sediakan oleh pihak bank. Namun, permasalahan yang sering terjadi di masyarakat umumnya adalah mencari lokasi ATM di daerah sekitarnya maupun di daerah yang baru di datangi serta tidak ada keinginan untuk bertanya pada warga sekitar dimana lokasi ATM terdekat. Sehingga pengembang aplikasi membuat aplkasi pencarian lokasi ATM dengan memanfaatkan SIG ( Sistem Informasi Geografis dab aplikasi ini diharapkan dapat membantu masyarakat dalam mencari lokasi ATM BNI terdekat diwilayah kota serang. Program yang akan dibangun, dengan merancang tampilan input dan tampilan output program. Pada perancangan ini menggunakan UML (Unified Modeling Language) untuk merancang aplikasinya. Dan penulisan program terhadap desain yang sudah di rancang dan menentukan bahasa pemrograman yang digunakan Android Studio 2.2, PHP dan MySQL.
\end{abstract}

Kata Kunci : Sistem Informasi Geografis, ATM, Android

\section{PENDAHULUAN}

Seiring berjalannya waktu, kebutuhan masyarakat modern akan teknologi dengan mobilitas yang tinggi semakin meningkat. Khususnya dalam keperluan manajemen finansial. Segala transaksi tidak luput dari peran mesin ATM sebagai pendukung terciptanya peningkatan finansial seseorang atau badan usaha. Maka dari itu, keberadaan mesin ATM sekarang ini sudah menjadi kebutuhan umum masyarakat modern.

Aplikasi android yang sekarang ini tersedia untuk pengguna GPS sebagian besar belum memiliki fungsi lengkap. Di aplikasi pencarian mesin ATM terdekat ini misalnya, aplikasi android yang berfungsi untuk membantu kita menemukan mesin ATM terdekat dari posisi pengguna berdasarkan GPS. Dimana melihat secara garis besar bahwa masyarakat membutuhkan aplikasi yang dapat membantu mereka untuk mencari lokasi berdasarkan posisi mereka saat ini, terutama ketika mereka sedang berpergian ke suatu tempat wisata atau tempat yang belum pernah mereka kunjungi sebelumnya. Sehingga terkadang mengalami kesulitan mencari mesin ATM dan mengataahui ATM yang sedang rusak,saat ini pengguna android di Indonesia terus bertambah dan luas dibilang sudah menjadi mayoritas dibandingkan platform lain, serta pengguna android tersebut memiliki ketertarikan terhadap aplikasi pencarian mesin ATM.

Berdasarkan latar belakang tersebut maka dibutuhkan sebuah sistem yang dapat menunjukkan informasi ATM secara geografis, yaitu Sistem Informasi Geografis (SIG) yang dapat di gunakan oleh nasabah Bank BNI sebagai informasi pendukung dalam mencari lokasi mesin ATM terdekat dari tempat mereka berada dengan informasi lebih detail dan mengetahui ATM yang sedang rusak.

\section{METODOLOGI PENELITIAN}

Metodologi yang digunakan dalam penelitian ini meliputi : Studi Pustaka, Observasi dan wawancara, selain itu melakukan metode perancangan sistem sebagai berikut :

2.1 Analisa System

Analisis sistem adalah sistem yang berjalan dengan tujuan untuk mendesain sistem baru yang mentempurnakan sistem lama.

Rincian tujuan dari tahapan sistem analis adalah:

a. Membuat keputusan apabila sistem ini mempunyai masalah atau tidak berfungsi dengan baik dan hasil analisisnya digunakan sebagai dasar untuk memperbaiki sistem.

b. Mengetahui ruang lingkup pekerjaan yang akan ditanganinya.

c. Memahami sistem yang berjalan saat ini.

d. Mengidentifikasikan masalah dan mencari solusinya.

2.2 UML (Unified Modelling Language)

Unified Modeling Language (UML) adalah bahasa spesifikasi standar untuk mendokumentasikan, menspesifikasikan, dan membangun system. Unified Modeling Language (UML) adalah himpunan struktur dan teknik untuk pemodelan desain program berorientasi objek (OOP) serta aplikasinya. 
UML adalah metodologi untuk mengembangkan sistem OOP dan sekelompok perangkat tool untuk mendukung pengembangan sistem tersebut. UML mulai diperkenalkan oleh Object Management Group, sebuah organisasi yang telah mengembangkan model, teknologi, dan standar OOP sejak tahun 1980-an. Sekarang UML sudah mulai banyak digunakan oleh para praktisi OOP. UML merupakan dasar bagi perangkat (tool) desain berorientasi objek dari IBM. (Herlawati, 2011:1).

Masing-masing metodologi membawa notasi sendirisendiri, yang mengakibatkan timbul masalah baru apabila kita bekerjasama dengan kelompok/perusahaan lain yang menggunakan metodologi yang berlainan. Dimulai pada bulan Oktober 1994 Booch, Rumbaugh dan Jacobson, yang merupakan tiga tokoh yang boleh dikatan metodologinya banyak digunakan mempelopori usaha untuk penyatuan metodologi pendesainan berorientasi objek. Pada tahun 1995 direlease draft pertama dari UML (versi 0.8). Sejak tahun 1996 pengembangan tersebut dikoordinasikan oleh Object Management Group (OMG ).

\section{HASIL DAN PEMBAHASAN}

\subsection{Perancangan Sistem}

\subsubsection{Diagram Use Case}

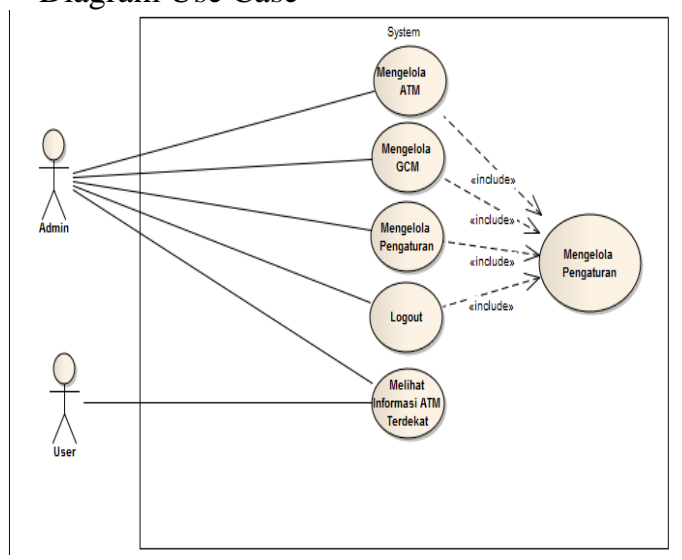

Gambar 1 Diagram Use Case

3.1.2 Activity Diagram Login

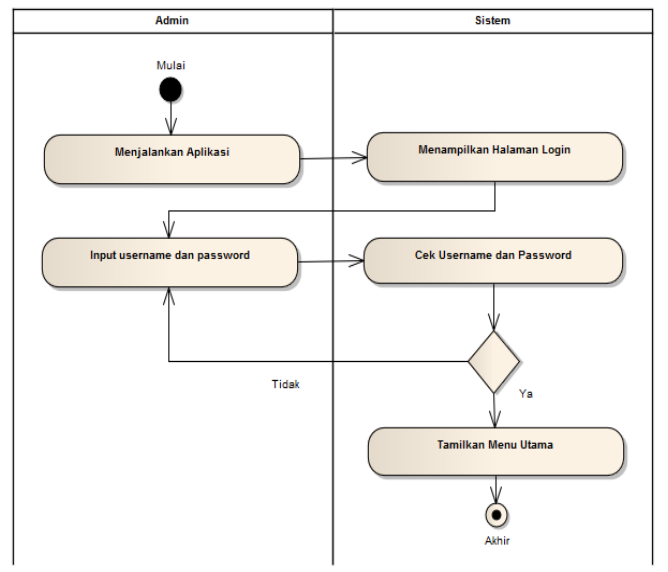

Gambar 2 Activity Diagram login

\subsubsection{Activity Diagram Menu ATM}

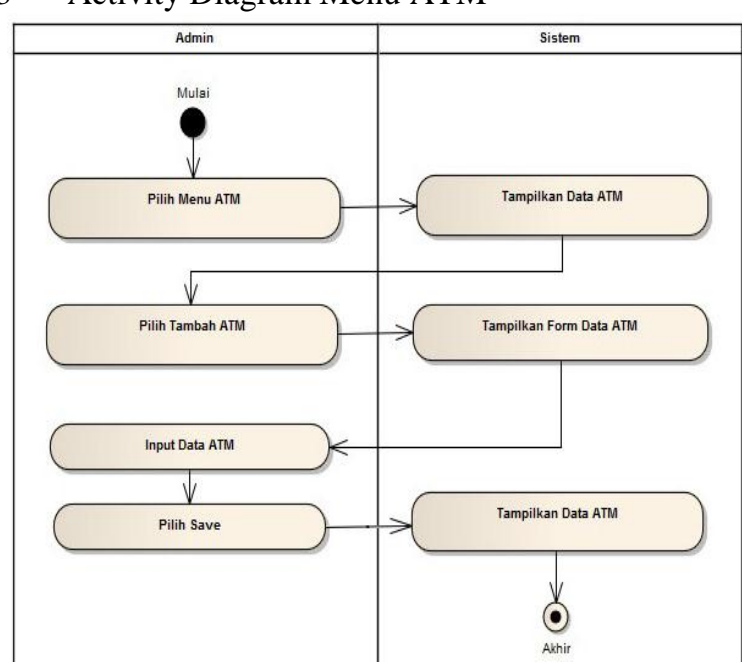

Gambar 3 Activity Diagram Menu ATM

\subsubsection{Actifity Diagram Menu GCM}

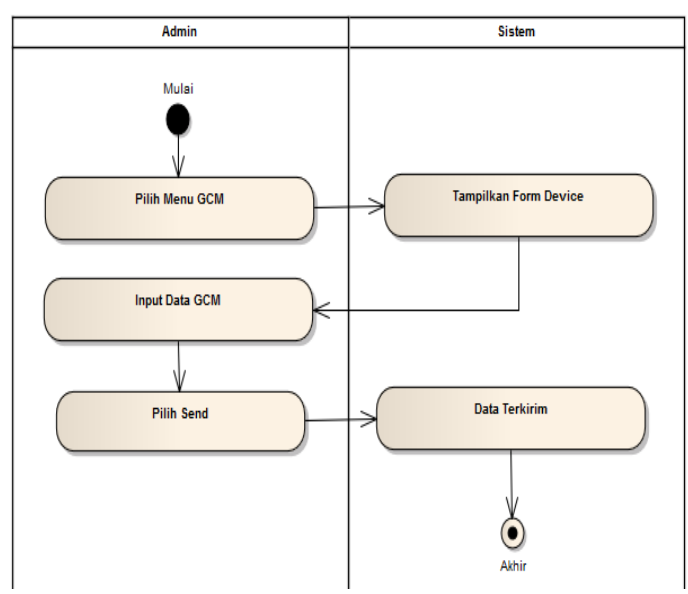

Gambar 4 Activity Diagram Menu GCM

\subsubsection{Actifity Diagram Menu Pengaturan}

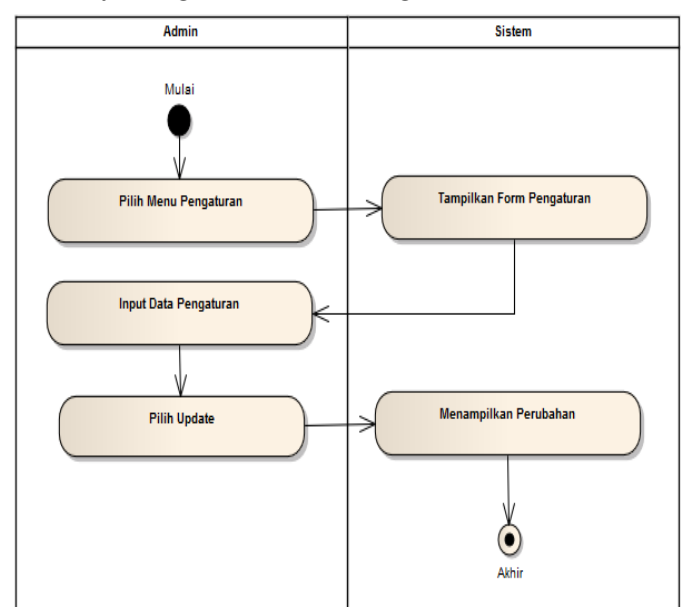

Gambar 5 Activity Diagram Menu Pengaturan 
3.1.6 Actifity Diagram Menu Log out

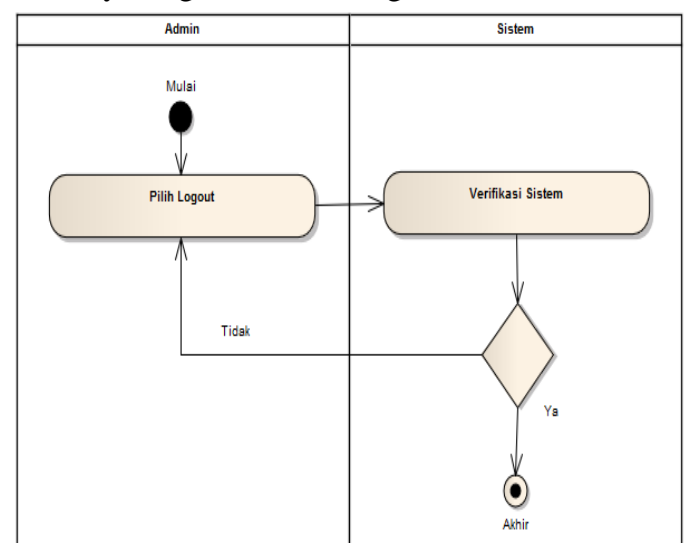

Gambar 6 Activity Diagram Menu Log Out

3.1.7 Actifity Diagram Menu Informasi ATM terdekat

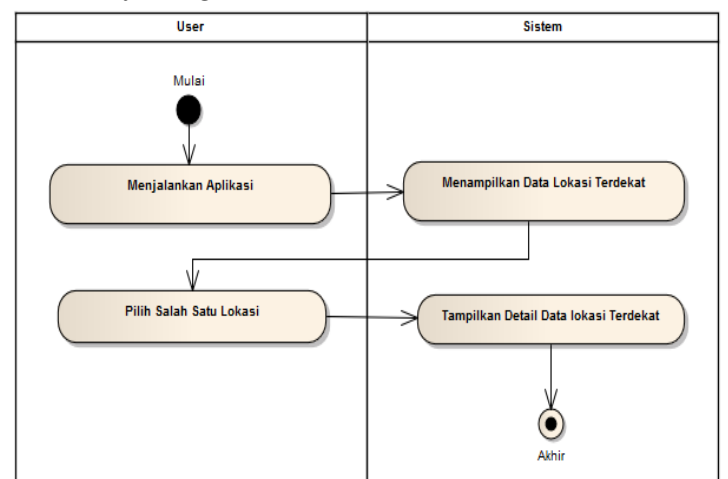

Gambar 7 Menu Informasi ATM terdekat

3.1.8 Sequence Diagram Login

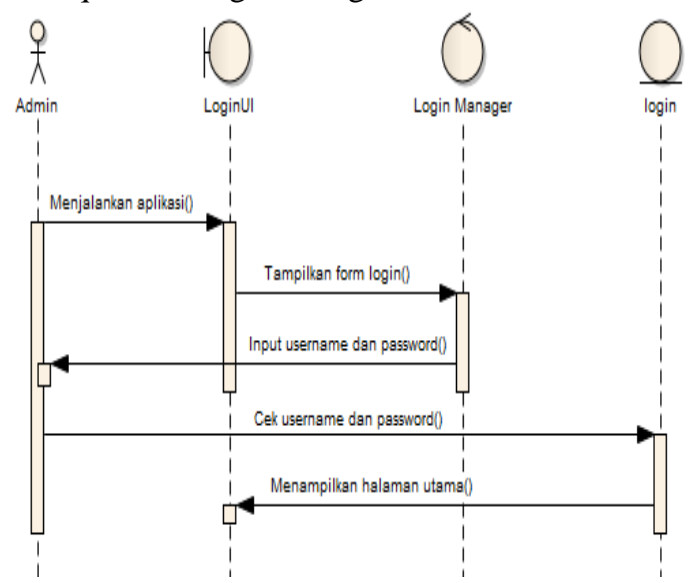

Gambar 8. Sequence Diagram Login
3.1.9 Sequence Diagram ATM

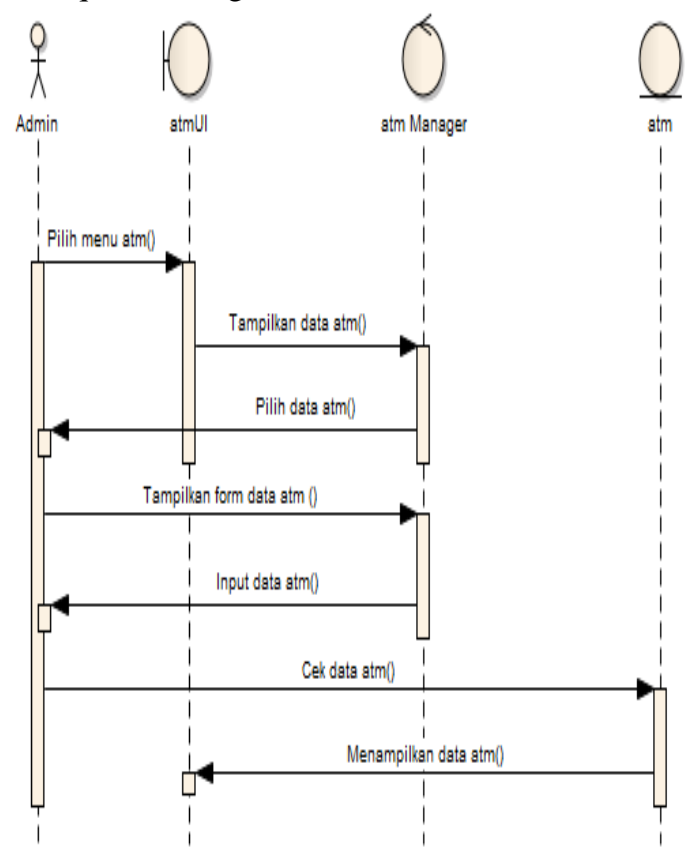

Gambar 9. Sequence Diagram ATM

3.1.10 Sequence Diagram GCM

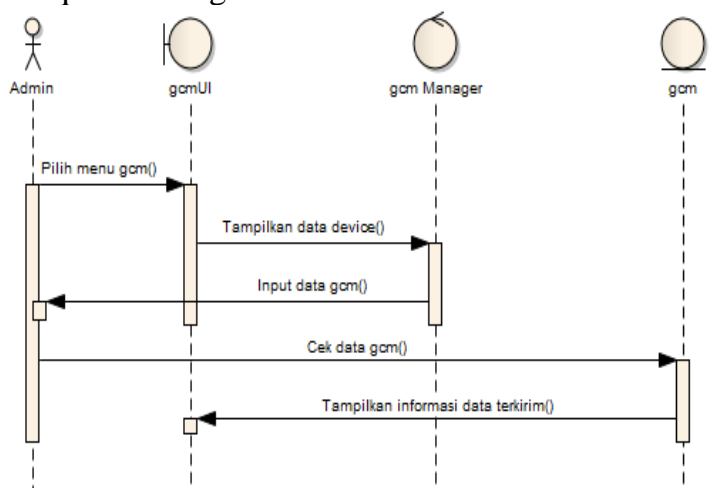

Gambar 10. Sequence Diagram GCM

3.1.11 Sequence Diagram Pengaturan

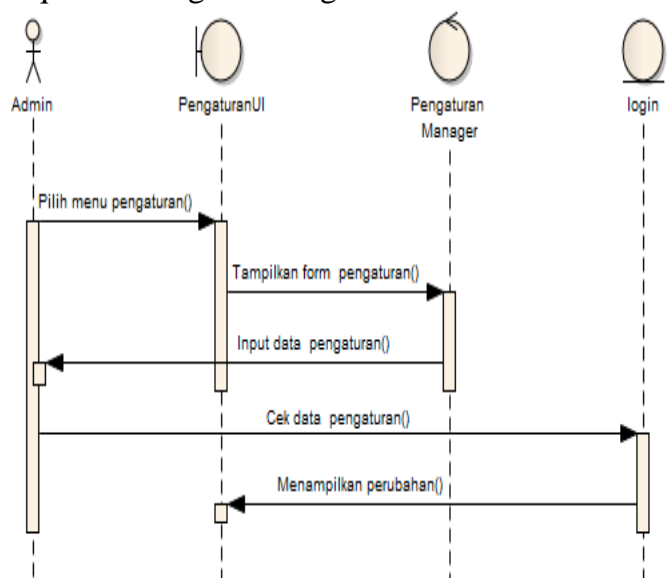

Gambar 11. Sequence Diagram Pengaturan 
3.1.12 Sequence Diagram Log Out<smiles>CC(C)(C)O</smiles>

Admin

i

।<smiles>C1CCCCC1</smiles>

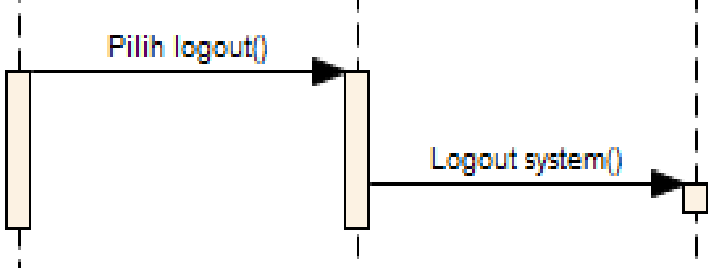

Gambar 12. Sequence Diagram Logout

3.1.13 Sequence Diagram Informasi ATM Terdekat

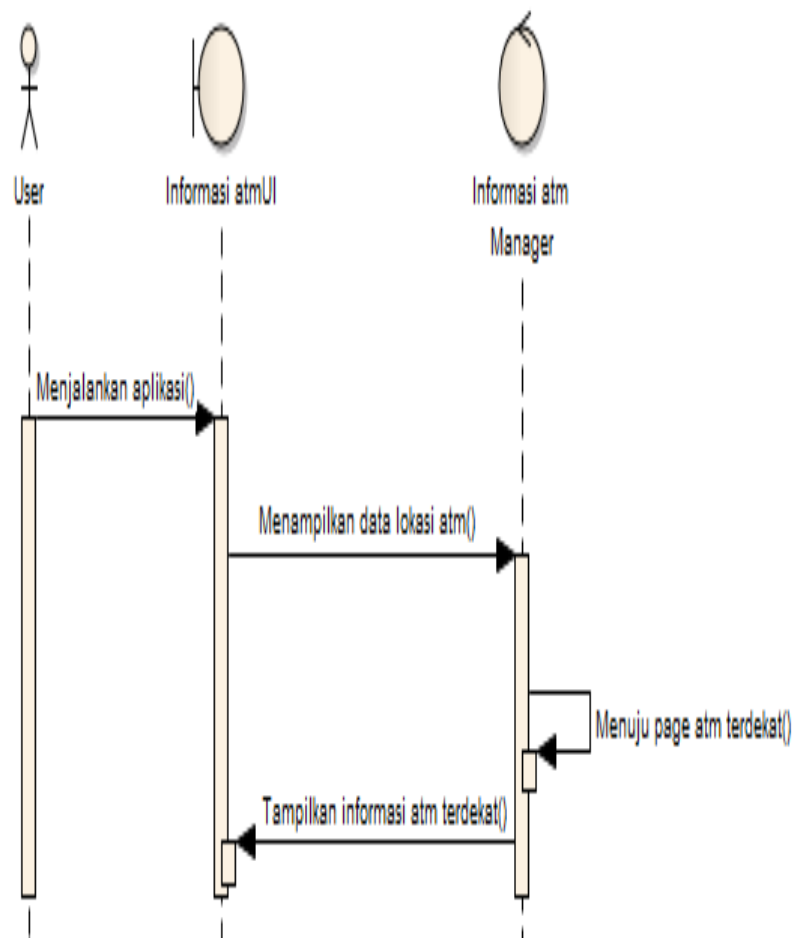

Gambar 13. Sequence Diagram Informasi ATM Terdekat

\subsubsection{Class Diagram}

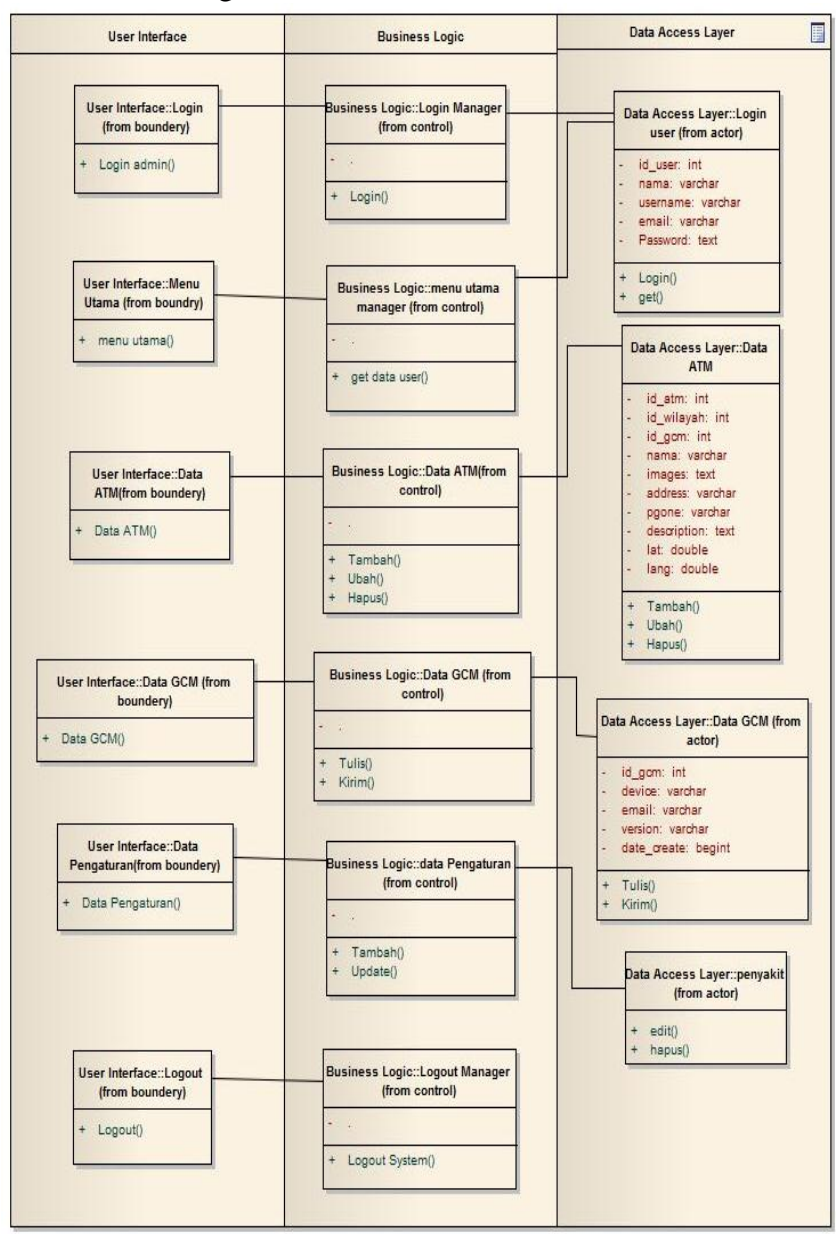

Gambar 14. Class Diagram

3.1.15 Implementasi antar muka back end Halaman Login

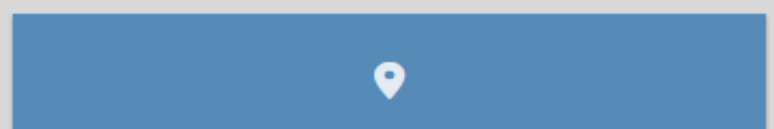

\section{LOGIN}

Gambar 15. Halaman Login 
Halaman Home

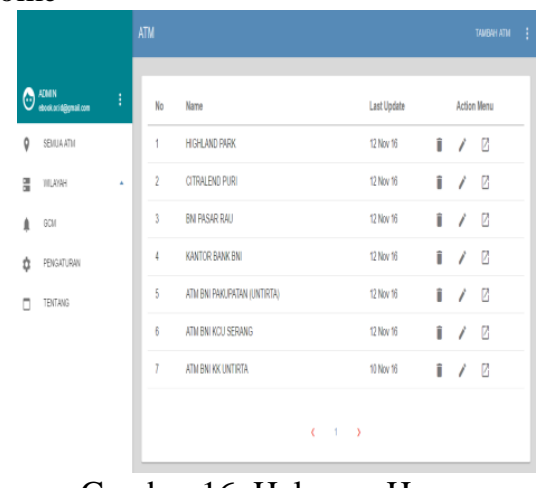

Gambar 16. Halaman Home

Halaman Menu Wilayah

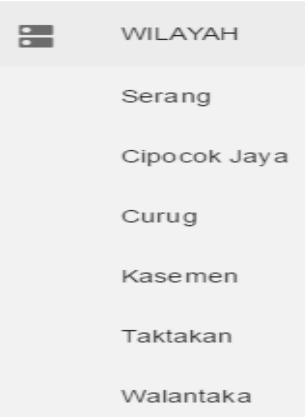

Gambar 17. Halaman Menu Wilayah

Halaman Menu GCM

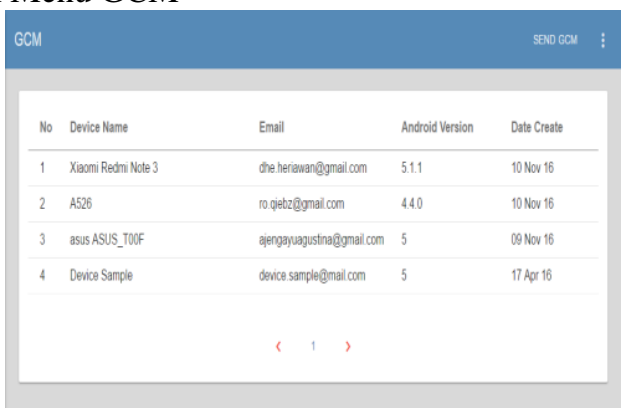

Gambar 18. Halaman Menu GCM

Halaman Information Device

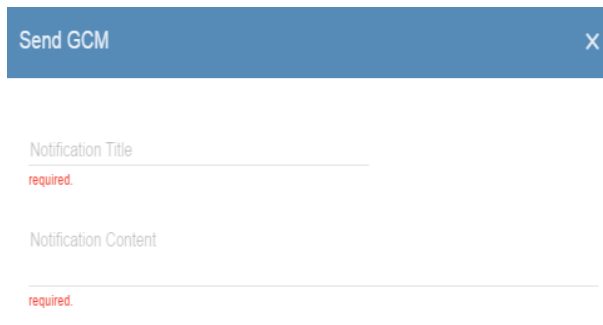

This data will be displayed on the user's phone notification

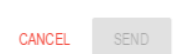

Gambar 19. Halaman Information Device
Halaman Pengaturan

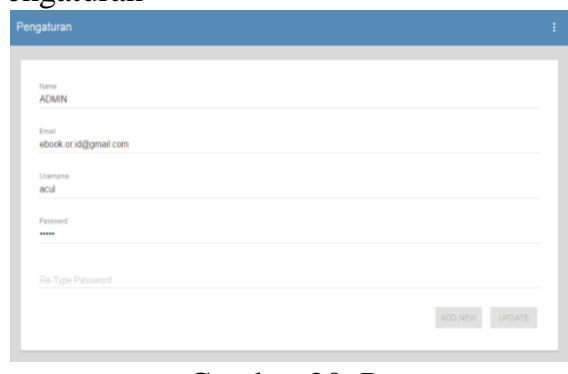

Gambar 20. Pengaturan

Halaman tentang SIG ATM

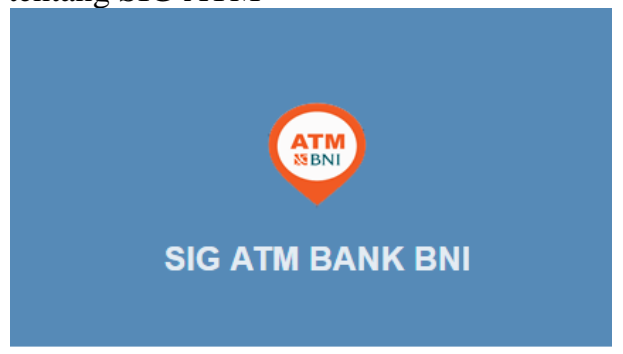

bni.co.id

Gambar 21 Halaman SIG ATM

3.1.16 Halaman Antar Muka Front End Halaman Splash Screen

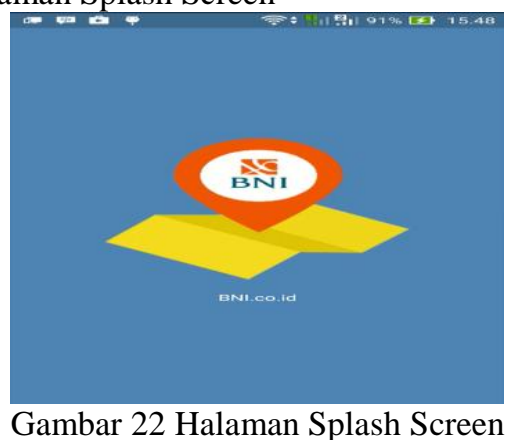

Halaman Home Android

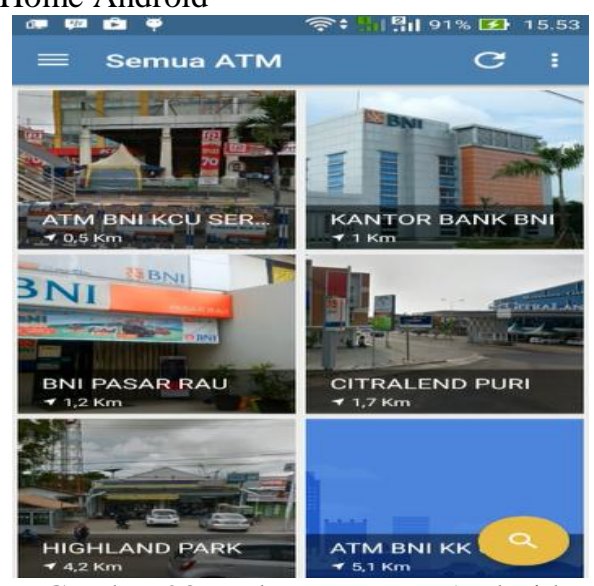

Gambar 23. Halaman Home Android 
Halaman Navigasi

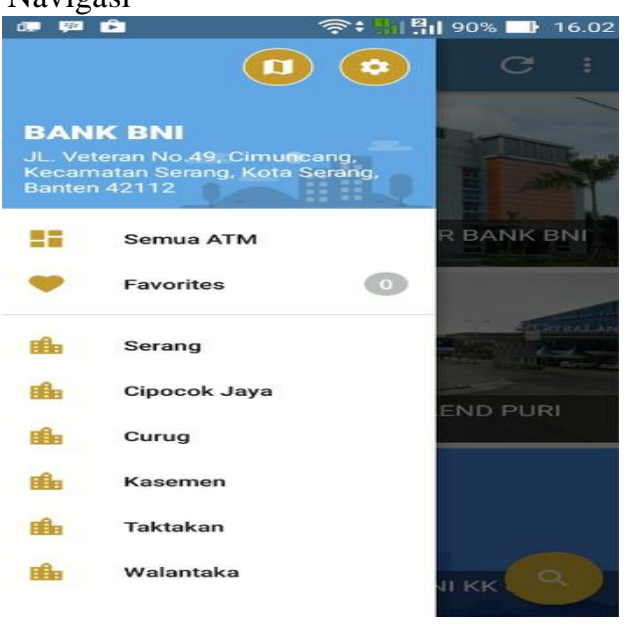

Gambar 24. Halaman navigasi

Halaman lokasi terpilih

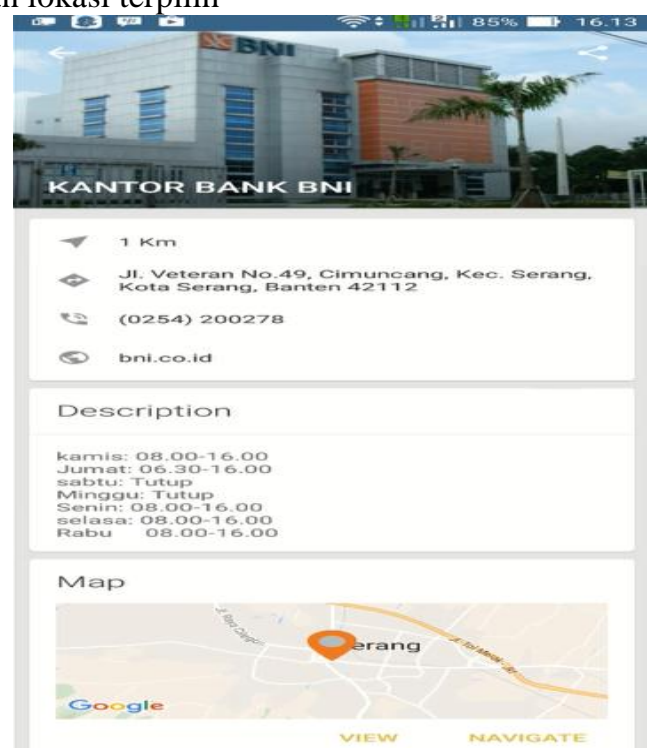

Gambar 25. Halaman lokasi terpilih

3.1.17 Pengujian System

Tabel 1 Pengujian Sistem

\begin{tabular}{|c|c|c|c|c|}
\hline $\begin{array}{c}\text { Identifi } \\
\text { kasi }\end{array}$ & Prosedur Pengujian & Keluaran & $\begin{array}{c}\text { Hasil } \\
\text { Pengujia } \\
\mathrm{n}\end{array}$ & $\begin{array}{c}\text { Kesimpul } \\
\text { an }\end{array}$ \\
\hline $\begin{array}{l}\text { Penguj } \\
\text { ian } \\
\text { login }\end{array}$ & $\begin{array}{l}\text { - Masukan data } \\
\text { username dan } \\
\text { password. } \\
\text { - Tekan tombol } \\
\text { login. }\end{array}$ & $\begin{array}{l}\text { Masuk } \\
\text { kehalaman } \\
\text { utama }\end{array}$ & $\begin{array}{l}\text { Berhasil } \\
\text { masuk }\end{array}$ & Sukses \\
\hline $\begin{array}{l}\text { Penguj } \\
\text { ian } \\
\text { Tamba } \\
\text { h ATM }\end{array}$ & $\begin{array}{l}\text {-Klik menu semua } \\
\text { ATM } \\
\text {-Klik tombol tambah } \\
\text { ATM } \\
\text {-Masukan data nama } \\
\text { tempat, address, } \\
\text { phone, wilayah, } \\
\text { imgae primary, } \\
\text { description, } \\
\text { coordinate. }\end{array}$ & $\begin{array}{l}\text { Data lokasi } \\
\text { ATM } \\
\text { berhasil di } \\
\text { simpan }\end{array}$ & $\begin{array}{l}\text { Data } \\
\text { berhasil } \\
\text { disimpan }\end{array}$ & Sukses \\
\hline
\end{tabular}

\begin{tabular}{|l|l|l|l|l|}
\hline $\begin{array}{l}\text { Identifi } \\
\text { kasi }\end{array}$ & Prosedur Pengujian & Keluaran & $\begin{array}{c}\text { Hasil } \\
\text { Pengujia } \\
\text { n }\end{array}$ & $\begin{array}{c}\text { Kesimpul } \\
\text { an }\end{array}$ \\
\hline $\begin{array}{l}\text { Penguj } \\
\text { ian } \\
\text { wilaya } \\
\text { h }\end{array}$ & $\begin{array}{l}\text { Klik kategori } \\
\text { wilayah }\end{array}$ & $\begin{array}{l}\text { Keluar } \\
\text { daftar } \\
\text { wilayah }\end{array}$ & $\begin{array}{l}\text { Berhasil } \\
\text { menampi } \\
\text { lkan } \\
\text { daftar } \\
\text { wilayah }\end{array}$ & Sukses \\
\hline $\begin{array}{l}\text { Penguj } \\
\text { ian } \\
\text { GCM }\end{array}$ & $\begin{array}{l}\text { - Klik menu gcm } \\
\text { - Masukan data } \\
\text { notification titile, } \\
\text { - Tekan tombol send }\end{array}$ & $\begin{array}{l}\text { Data } \\
\text { notifikasi } \\
\text { berhasil di } \\
\text { kirim }\end{array}$ & $\begin{array}{l}\text { Data } \\
\text { notifikasi } \\
\text { berhasil } \\
\text { di kirim }\end{array}$ & Sukses \\
\hline $\begin{array}{l}\text { Penguj } \\
\text { ian } \\
\text { Pengat } \\
\text { uran }\end{array}$ & $\begin{array}{l}\text { - klik menu } \\
\text { pengaturan } \\
\text {-Masukan data user } \\
\text { yang baru atau }\end{array}$ & $\begin{array}{l}\text { Pengaturan } \\
\text { berhasil } \\
\text { dirubah }\end{array}$ & $\begin{array}{l}\text { Pengatur } \\
\text { an } \\
\text { berhasil } \\
\text { dirubah }\end{array}$ & Sukses \\
\hline
\end{tabular}

\section{KESIMPULAN}

Berdasarkan hasil pembahasan aplikasi pemetaan SIG ATM BNI Kota Serang, maka kesimpulan yang dapat diambil adalah sebagai berikut:

1. Aplikasi mobile SIG ATM BANK BNI di Kota Serangdibangun dengan menggunakan rancangan permodelan UML (Unified Modeling Language) yang terdiri dari Use Case Diagram, Class Diagram, Activity Diagram, Sequence Diagram dan dibuat dengan menggunakan Android Studio, Sistem Informasi Geografis Interfacenya di rancang sesederhana mungkin agar bisa digunakan oleh semua nasabah BANK BNI dan aplikasi ini mampu memberikan informasi lokasi ATM terdekat dan mengetahui ATM yang sedang rusak.

2. Sistem informasi Geografi ATM BNI diwilayah kota serang dapat diterapkan oleh pengguna android dimanapun dan kapanpun, sehingga dapat memudahkan pengguna untuk mengakses ATM BNI terdekat diwilayah kota serang

Demikian beberapa saran yang dapat dipergunakan sebagai pertimbangan untuk pengembangan aplikasi pada penelitian selanjutnya.

1. Diharapkan SIG ATM BNI ini diperluas ke daerah lainnya.

2. Mengembangkan aplikasi dengan platform lain seperti Windows atau Iosagar dapat di gunakan oleh system operasi lain.

\section{REFERENSI}

[1] Abdul Fatah, Agung Budi Cahyono. 2014. Sistem Informasi Geografis ATM (Automatic Teller Machine) Dan Mini Market Terdekat Berbasis Android 2.2

[2] Dr. Ir. Muhammad Taufik, Ayuarisa Ika Wandini. 2012. Pengembangan Websig Obyek Wisata Dan Budaya Di Kabupaten Mojokerto

[3] Kasmir, S.E., M.M. (2011). Bank Dan Lembaga Keuangan Lainnya. Jakarta:Rajawali Pers

[4] Purba Setyo Baskoro, Ahmad Syauqi Ahsan, Arif Basofi. 2014. Sistem Pengambilan Keputusan Penempatan Atm (Automated Teller Machine) Berdasarkan Penyebaran Nasabah Di Surabaya Menggunakan Gis 
[5] Sugianto, Arna Fariza 2011. Sistem Informasi Geografis Untuk Pemetaan Dan Analisadaerah Pertanian Di Kabupaten Ponorogo

[6] Safaat H, Nazaruddin. (2011). Pemrograman Aplikasi Mobile Smartphone dan Tablet PC Berbasis Android. Bandung: Informatika

[7] Vinsensia Hutagaol, Bambang Sudarsono, Arief Laila Nugraha. 2015. Penentuan Potensi Lokasi Atm Bni Menggunakan Analytical Hierarchy Process (Ahp) Dan Sistem Informasi Geografis (Studi Kasus : Kecamatan Tembalang)

[8] Yusuf Mufti. (2015).Panduan Mudah Pengembangan Google Map Android. Jakarta: Andi Publisher 